九州大学学術情報リポジトリ

Kyushu University Institutional Repository

\title{
Analys is of Evolved Species and Estimation of the Combustion Emissions of PACB and AAC Preservatives Using TGA-IR and CEM Techniques
}

Lin, Han Chien

Laboratory of Environment Functional Materials, Department of Forest Products Science, College of Agriculture, National Chiayi University

Murase, Yasuhide

Laboratory of Wood Material Technology, Division of Biomaterial Science, Department of Forest and Forest Products Sciences, Faculty of Agriculture, Kyushu University

https://doi.org/10.5109/14064

出版情報：九州大学大学院農学研究院紀要. 54 (1)，pp.223-229，2009-02-27. Faculty of Agriculture, Kyushu University

バージョン :

権利関係 : 


\title{
Analysis of Evolved Species and Estimation of the Combustion Emissions of PACB and AAC Preservatives Using TGA-IR and CEM Techniques
}

\author{
Han Chien LIN ${ }^{1}$ and Yasuhide MURASE ${ }^{2}$
}

\author{
Laboratory of Wood Material Technology, Division of Biomaterial Science, Department of Forest and \\ Forest Products Sciences, Faculty of Agriculture, Kyushu University, \\ Fukuoka 812-8581, Japan \\ (Received November 11, 2008 and accepted December 5, 2008)
}

\begin{abstract}
Alkyl Ammonium Compound (AAC) and Protein Ammonia Copper Borate (PACB) are two types of waterborne preservatives. In this paper they were examined, first by using thermogravimetric analysis (TGA) under different heating rates ( 5 or $40^{\circ} \mathrm{C} / \mathrm{min}$ ), second by using thermogravimetric analysis with infrared spectrometry (TGA-IR), and third by using continuous emission monitoring (CEM) techniques. The results obtained from the TGA tests found that the decomposition temperature of AAC and PACB at the heating rate of $5{ }^{\circ} \mathrm{C} / \mathrm{min}$ was lower than that at $40^{\circ} \mathrm{C} / \mathrm{min}$. Regardless of the different heating rates, the decomposition temperatures of PACB were all higher than those for AAC, and the char (wt \%) of the PACB (65.38 wt $\%$ for $5{ }^{\circ} \mathrm{C} / \mathrm{min}$ and $66.92 \mathrm{wt} \%$ for $\left.40{ }^{\circ} \mathrm{C} / \mathrm{min}\right)$ was more than that of the AAC $\left(0.042\right.$ wt $\%$ for $5{ }^{\circ} \mathrm{C} /$ min and $0.046 \mathrm{wt} \%$ for $\left.40^{\circ} \mathrm{C} / \mathrm{min}\right)$. The IR response of AAC and PACB in the TGA-IR tests showed that at a heating rate of $5^{\circ} \mathrm{C} / \mathrm{min}$, the evolved species of AAC were less than those of PACB. However, at a heating rate of $40^{\circ} \mathrm{C} / \mathrm{min}$ the numbers of evolved species of AAC were much higher than those of PACB. Considering the decomposition step (thermal time or temperature) at different heating rates in the TGA tests and the IR response from the TGA-IR analysis, the results showed that at the slow-heating regime, the concentrations of $\mathrm{CO}_{2}$ and the evolved species of $=\mathrm{CH}_{2}$ groups produced by PACB were higher than those of $\mathrm{AAC}$, but at $40^{\circ} \mathrm{C} / \mathrm{min}$ the results were reversed. The results of combustion emissions obtained by CEM techniques found that the emission gas temperature of AAC was higher than that of PACB. Both $\mathrm{O}_{2}$ and $\mathrm{CO}_{2}$ reached a plateau curve until the end of combustion, during which time they were closely related. The highest emission quantity of CO was about $94.0 \mathrm{ppm}$ for AAC, but it was $120.0 \mathrm{ppm}$ for PACB. The emission quantity of $\mathrm{SO}_{2}$ for each type of sample was zero. The maximum NOx for AAC was about $49.5 \mathrm{ppm}$, but it was insignificant for the amount of PACB during combustion. The above results of the TGA-IR and CEM analysis allowed us to determine the kinds of evolved species and the emission gas concentrations of $\mathrm{O}_{2}$ and $\mathrm{CO}_{2}$, the emission contents ( $\left.\mathrm{CO}, \mathrm{SO}_{2}, \mathrm{NOx}\right)$, and the temperature of the emission gases for referencing the thermo-decomposition processes of AAC and PACB during combustion.
\end{abstract}

Keywords: Alkyl Ammonium Compound (AAC), Protein Ammonia Copper Borate (PACB), Char, Evolved Species, Combustion Emissions

\section{INTRODUCTION}

Wood preservatives have been used to preserve wood from insects, fungi and water damage for the past few decades. This is due to the fact that preservatives provide an extra layer of protection for any wood product when used for any outdoor application. Waterborne (water-based) preservatives are often used when cleanliness, printability and objectionable odor of the treated woods are required. These preservatives include chromated copper arsenate (CCA), ammoniacal copper quats (ACQ), and others. Other preservatives in CNS 14495 O 1048 include alkyl ammonium compound (AAC), ammo-

\footnotetext{
Laboratory of Environment Functional Materials, Department of Forest Products Science, College of Agriculture, National Chiayi University, Chiayi, Taiwan, ROC. Corresponding author (E-mail: alexhlin@mail.ncyu.edu.tw)

Laboratory of Wood Material Technology, Division of Biomaterial Science, Department of Forest and Forest Products Sciences, Faculty of Agriculture, Kyushu University, Japan.
}

niacal copper azole (CuAz), inorganic boron (borax/boric acid), etc. Boron preservatives are very effective against decay, termites, beetles, and carpenter ants (Ibach, 1999), but they provide little resistance to leaching after the wooden has been used above ground where it is protected from wetting for a longer period of time. One of the more common formulations used in Taiwan contains mainly copper and borate, and is known as protein ammonia copper borate (PACB) because protein, especially the feather protein used, has shown high resistance to leaching and has proven to be a very good performer for wood and bamboo products (Fan, 2003; Mazela and Izabela, 2003; Chang et al., 2004).

At present much attention is being given to the disposal of wood preservatives, because during combustion they emit toxic and corrosive gases (Cox, 1991; Cooper et al., 2003; Solo-Gabriele et al., 2003). Exposure to these toxic emissions is harmful to humans and in addition can cause damage to expensive equipment (Ladomersky, 2000; Kercher and Nagle, 2001). With the use of thermogravimetric analysis with infrared spectrometry (TGA-IR), it is possible to simultaneously monitor any evolved spe- 
cies, the decomposition temperature and the concentrations formed (absorbance), as well as the evolution profile of certain compounds. IR spectrometry is a common method for evaluating a functional base when a material undergoes degradation (Lin et al., 2004; Lin and Murase, 2007). At the same time, Continuous Emission Monitoring (CEM) techniques are widely utilized for detecting gaseous emissions such as $\mathrm{CO}, \mathrm{SO}_{2}, \mathrm{NOx}, \mathrm{O}_{2}$ and $\mathrm{CO}_{2}$ concentrations at the chimney exit of furnaces to determine the concentrations of various pollutants (Jang, 2000).

In our earlier works (Lin et al., 2007; Lin and Murase, 2007) we established some referable results for CCA and ACQ. One result was the emissions during combustion and the char after combustion. Another result was the use of TGA in combination with TGA-IR for analyzing the thermal behavior of 3 types of preservatives, which led to useful results, including the identification of pyrolysis products. To elucidate the comprehension of the thermal properties of AAC and PACB, a comparison was made between the slow-heating regime and the fastheating regime in an air atmosphere. The examinations were divided into three categories. The first category involved the study of thermal decomposition, and examined the effectiveness of the thermal properties of AAC and PACB using thermogravimetric analysis (TGA). In the second category, TGA-IR was applied to monitor the effectiveness, on an analytical scale, of the two waterbased preservatives and to examine the emissions of certain compounds in each particular analysis. The third category was applying CEM to analyze the combustion emissions during the combustion of both preservatives. The goal of this research was to acquire fundamental knowledge of the pyrolysis temperature (obtained from TGA), and the decomposition time of the evolved species from the IR response (obtained from TGA-IR) of $\mathrm{AAC}$ and $\mathrm{PACB}$, while at the same time obtaining an air pollution (obtained from CEM) reference for gas emissions. The obtained results were also compared with the results of CCA and ACQ from previous works (Lin et al., 2007; Lin and Murase, 2007).

\section{MATERIALS AND METHODS}

\section{Wood preservatives}

The basic properties of both commercial wood preservatives, provided by Te Feng Lumber Co. Ltd., Taiwan, are as follows:

a. Alkyl Ammonium Compound (AAC): This waterborne (water-based) preservative is light yellow in color, and its main content is 35\% didecyl dimethyl ammonium chloride (DDAC). The solid content is about 86.50 (0.001) \%, and its specific gravity is $0.890(0.001)$ at $27.0^{\circ} \mathrm{C}$, with a $\mathrm{pH}$ of 7.11 .

b. Protein Ammonia Copper Borate (PACB): PACB is deep blue in color, and basically consists of $43 \mathrm{~g}$ of protein with, $200 \mathrm{~mL}$ ammonia. The basic weight rate (\%) of copper to boron was $32 \mathrm{~g}$ of copper to $8 \mathrm{~g}$ boron with $996 \mathrm{~mL}$ water. Its effective content was $12.8\left(\mathrm{~kg} / \mathrm{cm}^{3}\right.$ ) (Chang et al.,
2004). The solid content was about 0.35 (0.01) $\%$, and its specific gravity was 1.007 (0.001) at $25.0^{\circ} \mathrm{C}$, with a pH of 9.78 .

\section{Thermogravimetric analysis (TGA)}

In this experiment, TGA was carried out using a Perkin-Elmer TGA 1, fully supported by computer-controlled software options from Perkin-Elmer Thermal Analysis Systems for control and data handling. The sampling and the analyzed conditions, including the air flow rate and two kinds of heating rate for the TGA tests were the same as in previous reports (Lin et al., 2006; Lin and Murase, 2007), except that the heating range was between 50 to $800{ }^{\circ} \mathrm{C}$ while the measurements were carried out.

\section{Thermogravimetric analysis with infrared spec- trometry (TGA-IR)}

This analysis was carried out using a TGA (PerkinElmer Pyris 7 TGA model), linked to a secondary method of analysis, the Fourier-Transform Infrared Spectroscopy (using a Perkin-Elmer FTIR), which was able to identify the evolved species during the TGA measurements (Statheropoulos and Kyriakou, 2000). The TGA and FTIR (TGA-IR) were connected using a transfer line with a continuous scanner in a gaseous cell. The infrared spectrometric (IR) response data was recorded by a personal computer. The spectrum time-based version 2.0 software (2000, Perkin-Elmer, Inc.) obtained and analyzed the evolved species as they occurred. The sampling and the calculation of the IR response obtained by the spectrum version 5.3 (2005, Perkin-Elmer, Inc.) were the same as for the previous report (Lin and Murase, 2007), and the conditions for heating and air flow rates were set the same as for the Perkin-Elmer TGA 1, described above. The evolved species analysis was performed for two kinds of water-based preservatives.

\section{Experimental combustion methods}

A Flue-gas Analyzer (MSI 2000, W. Germany) was used to examine the gas emitted from a flammability test cabinet (with reference to CNS 7614 A3125, NCYU handmade) during the combustion of AAC and PACB. The experimental design and tested methods for the CEM techniques were the same as for the previous reports (Lin et al., 2001; Lin and Huang, 2004; Lin, 2005; Lin et al., 2007). Six replicates of each sample of the preservatives, after first having been oven-dried, were placed individually into a crucible on a clay triangle with a triangular stand. The first cycle run in the flue-gas analyzer did not include combustion with a sample in the test cabinet to be certain that the measured value of various emission gases was zero, and that the gas temperature was at room temperature. The sample was ignited and then examined for 9 cycles continuously. The $\mathrm{CO}, \mathrm{SO}_{2}$ and NOx gases were measured in parts per million (ppm). The $\mathrm{O}_{2}$ and $\mathrm{CO}_{2}$ concentrations were defined as the volume percent (VOL \%) of the air in the emission exit. The gas temperature was measured at the same time. 


\section{RESULTS AND DISCUSSION}

\section{Thermal decomposition of AAC and PACB}

To comprehend the thermal properties of the AAC and PACB, the preservatives samples, after having been oven-dried, were measured by TGA. Decomposition profiles were obtained while the samples were being heated at a rate of 5 or $40^{\circ} \mathrm{C} / \mathrm{min}$ in air, between $50{ }^{\circ} \mathrm{C}$ (initial temperature) and $800^{\circ} \mathrm{C}$ (end temperature). The relationships between the TGA and DTG curves, the temperature and weight loss, and the derivative weight for AAC and PACB are shown in Fig. 1.

Regardless of the heating rate, both water-based preservatives typically showed a gradual weight loss. The thermogram, resulting from the analysis of $\mathrm{AAC}$ at a heating rate of $5^{\circ} \mathrm{C} / \mathrm{min}$ (solid line) and $40^{\circ} \mathrm{C} / \mathrm{min}$ (dash line), respectively, showed that there was a subtle change (shoulder) at temperatures between 50 and about $250{ }^{\circ} \mathrm{C}$. The onset of weight loss under air was observed at a temperature of $233.42^{\circ} \mathrm{C}$ for the heating rate of $5^{\circ} \mathrm{C} / \mathrm{min}$, and at a temperature of $282.09^{\circ} \mathrm{C}$ for the heating rate of $40^{\circ} \mathrm{C} / \mathrm{min}$. These findings are supported by the derivative (DTG) curves, which show the peak at a temperature of $236.37^{\circ} \mathrm{C}$ for $5{ }^{\circ} \mathrm{C} / \mathrm{min}$, and at a temperature of $287.52{ }^{\circ} \mathrm{C}$ for $40^{\circ} \mathrm{C} / \mathrm{min}$ (see bottom of Fig. 1). The amount of char for both heating rates, at a temperature of $800{ }^{\circ} \mathrm{C}, 5^{\circ} \mathrm{C} / \mathrm{min}$ was 0.042 wt $\%$ and for $40{ }^{\circ} \mathrm{C} / \mathrm{min}$ it was $0.046 \mathrm{wt} \%$.

The TGA results of PACB for both heating rate are also shown in Fig. 1. The weight loss of PACB at a heat-
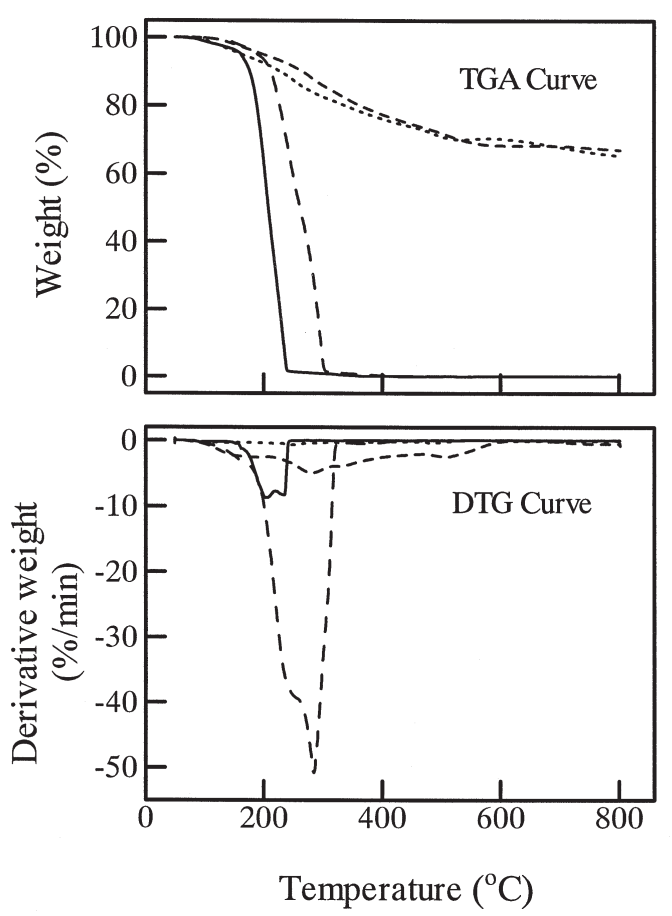

Fig. 1. TGA and DTG curves for 2 types of wood preservatives (AAC and PACB) in air at 5 or $40^{\circ} \mathrm{C} / \mathrm{min}$.

Symbols: — $\mathrm{AAC}\left(5^{\circ} \mathrm{C}\right) ;---$ : $\mathrm{AAC}\left(40^{\circ} \mathrm{C}\right)$; ......... PACB $\left(5^{\circ} \mathrm{C}\right) ;-$ - - - : PACB $\left(40^{\circ} \mathrm{C}\right)$

Notes: AAC: Alkyl Ammonium Compound; PACB: Protein Ammonia Copper Borate; $5{ }^{\circ} \mathrm{C}: 5^{\circ} \mathrm{C} / \mathrm{min}$ of heating rate; $40^{\circ} \mathrm{C}$ : $40^{\circ} \mathrm{C} / \mathrm{min}$ of heating rate. ing rate of either $5^{\circ} \mathrm{C} / \mathrm{min}$ (dotted line) and $40^{\circ} \mathrm{C} / \mathrm{min}$ (short dash line) showed that there were five shoulders for each heating rate, and the weight loss decreased gradually. The onsets of weight loss for the $40{ }^{\circ} \mathrm{C} / \mathrm{min}$ heating rate were observed at temperatures of $122.03,253.32$, $324.89,493.52$ and $697.17^{\circ} \mathrm{C}$, respectively. For the heating rate of $5^{\circ} \mathrm{C} / \mathrm{min}$, the weight loss was obvious at temperatures of $98.60,224.01,314.75,468.24$ and $605.11^{\circ} \mathrm{C}$, respectively. These findings are supported by the DTG curves of PACB (see bottom of Fig. 1). For PACB, the amount of char at a temperature of $800{ }^{\circ} \mathrm{C}$, was $65.38 \mathrm{wt}$ $\%$ at $5{ }^{\circ} \mathrm{C} / \mathrm{min}$ and 66.92 wt $\%$ at $40^{\circ} \mathrm{C} / \mathrm{min}$. These numbers are higher than those for AAC at either heating rate.

The above results showed that the decomposition temperatures of $\mathrm{AAC}$ and $\mathrm{PACB}$ for a heating rate of $5{ }^{\circ} \mathrm{C} / \mathrm{min}$ were lower than those at $40^{\circ} \mathrm{C} / \mathrm{min}$. Regardless of the heating rate, the decomposition temperatures of PACB were all higher than for AAC. This indicated that the thermal decomposition of AAC and PACB was influenced by the heating regimes in an air atmosphere. Compared to the char results of CCA and ACQ (Lin and Murase, 2007), the char of PACB was higher than that of ACQ-1 and lower than that of CCA. This is because PACB is a copper-based wood preservative (Ibach, 1999), and its main chemical composition includes protein, ammonia, copper and borate. Moreover, some researches (Hirata et al., 1993; Kercher and Nagle, 2001; Cooper et al., 2003; Helsen and Bulck, 2005; Lee et al., 2005) reported finding large amounts of $\mathrm{Cu}$ (copper) in the char of copper-based wood preservatives, such as CCA. Even for ACQ preservatives, a combination of copper and organic biocides, the char left a high amount of inorganic metal elements, $\mathrm{Cu}$, of about $50.14 \%$. It is evident that the $\mathrm{Cu}$ from the preservative (PACB) remains after combustion.

\section{Infrared spectrometric response of AAC and PACB}

Fig. 2 shows the infrared spectrometric (IR) response of the $\mathrm{AAC}$ and $\mathrm{PACB}$ for the heating rate of $5{ }^{\circ} \mathrm{C} / \mathrm{min}$ (on the left side of Fig. 2) and the heating rate of $40^{\circ} \mathrm{C} / \mathrm{min}$ (on the right side of Fig. 2) in the TGA-IR measurements. The changes in absorbance (concentration of evolved species, \%) correspond to the increase in decomposition time. For the IR response of AAC at a heating rate of $5^{\circ} \mathrm{C} / \mathrm{min}$ it was increased to about 1363.03 sec $\left(112.76{ }^{\circ} \mathrm{C}\right)$ from the start of decomposition. Subsequently, this tendency reduced to about 5088.24 $\sec \left(423.19^{\circ} \mathrm{C}\right)$. After that, the rate of change in concentration of evolved species increased until the end of decomposition. The IR response of PACB at a heating rate of $5{ }^{\circ} \mathrm{C} / \mathrm{min}$ rose linearly to about $5759.29 \mathrm{sec}$ $\left(479.11^{\circ} \mathrm{C}\right)$. Subsequently, this tendency reduced to about $6777.74 \mathrm{sec}\left(563.98^{\circ} \mathrm{C}\right)$. After that, the high point of absorbance occurred at the end of the decomposition. This suggests that at a heating rate of $5^{\circ} \mathrm{C} / \mathrm{min}$, the concentration of evolved species for PACB is higher than that for AAC.

The right side of Fig. 2 also shows the IR response of the AAC and PACB at the heating rate of $40{ }^{\circ} \mathrm{C} / \mathrm{min}$ in the TGA-IR measurements. The changes in concentra- 

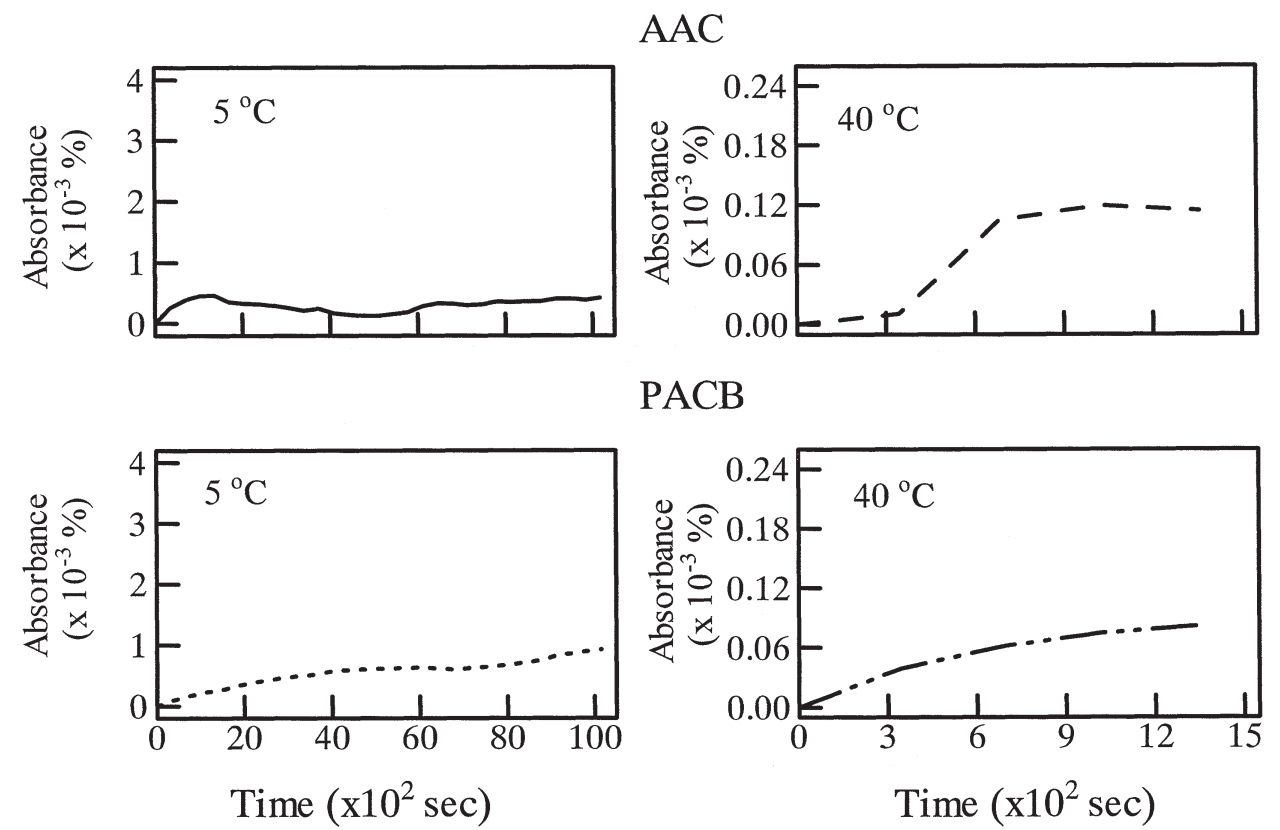

Fig. 2. IR response of 2 types of wood preservatives (AAC and PACB) in air at 5 or $40{ }^{\circ} \mathrm{C} / \mathrm{min}$ from TGA-IR analysis.

Symbols: The symbols are the same as Figure 1.

Note: Abbreviations of AAC, PACB and $5{ }^{\circ} \mathrm{C}, 40^{\circ} \mathrm{C}$ are the same as Figure 1.

tion of evolved species also correspond to the increase in decomposition time for the two preservatives. For the AAC, it slowly increased to about $344.08 \mathrm{sec}\left(222.72^{\circ} \mathrm{C}\right)$ from the start of decomposition. Subsequently, the increase in decomposition rose linearly to about 681.83 $\sec \left(447.88^{\circ} \mathrm{C}\right)$, and then leveled off until the end of decomposition. The change in absorbance for PACB slowly increased until the end of decomposition. Comparing the IR response of both preservatives at both heating rates, it was found that the absorbance levels at $5{ }^{\circ} \mathrm{C} / \mathrm{min}$ for PACB were higher than those for AAC. However, at $40^{\circ} \mathrm{C} / \mathrm{min}$ the results were reversed. This indicates that for wood preservatives the concentration of evolved species is related to the heating rate and the chemical composition, because of the variation in decomposition steps (Fig. 1).

\section{TGA-IR spectra of AAC and PACB}

The evolution of decomposition time (or temperature) on absorbance and wavenumbers (basically the IR spectra) for AAC and PACB is shown in Fig. 3. The distribution of wavenumbers at the end of each $600 \mathrm{sec}$ period for the heating rate of $5{ }^{\circ} \mathrm{C} / \mathrm{min}$ (the left side of Fig. 3) and at the end of each $100 \mathrm{sec}$ period for $40^{\circ} \mathrm{C} / \mathrm{min}$ (the right side of Fig. 3), during decomposition, was analyzed.

The TGA-IR spectra of AAC and PACB at a heating rate of $5{ }^{\circ} \mathrm{C} / \mathrm{min}$ are shown in the left side of Fig. 3. For the AAC, the range from $1800 \mathrm{sec}$ (at a temperature of about $149^{\circ} \mathrm{C}$ in the TGA tests) to the end showed a strong peak at $2934 \mathrm{~cm}^{-1}$, which was attributed to $=\mathrm{CH}_{2}$ groups with a symmetric stretching vibration. The carbon dioxide $\left(\mathrm{CO}_{2}\right)$ peak, located at $2296 \mathrm{~cm}^{-1}$, showed up around $3600 \sec \left(349^{\circ} \mathrm{C}\right)$ and remained steady to the end.
Another $\mathrm{CO}_{2}$ weak peak was located at $669 \mathrm{~cm}^{-1}$ and remained there from about $2400 \mathrm{sec}\left(249^{\circ} \mathrm{C}\right)$ to the end. In addition, some of the weak peaks at 3791, 1744, 1278, 1100 and $732 \mathrm{~cm}^{-1}$ were due to the $\mathrm{N}-\mathrm{H}$ stretching of $\mathrm{NH}_{2}$ moieties, $\mathrm{C}=\mathrm{O}$ (carbonyl group) stretching, the group of $\mathrm{N}-\mathrm{NO}_{2}$ stretching, $\mathrm{C}-\mathrm{O}$ stretching and $-\mathrm{OH}$ out-of plane wagging from about $1200 \mathrm{sec}\left(149^{\circ} \mathrm{C}\right)$ to the end. For $\mathrm{PACB}$, the stronger peaks, at $3752,3620,1714$, and $1574 \mathrm{~cm}^{-1}$, were due to the $\mathrm{N}-\mathrm{H}$ stretching of $\mathrm{NH}_{2}$ moieties, the $\mathrm{OH}$ group, $\mathrm{C}=\mathrm{O}$ stretching and the group of $\mathrm{C}-\mathrm{N}$ stretching, all ranging from the beginning of the combustion to the end. These numbers all showed an increasing trend, especially the N-H stretching of $\mathrm{NH} 2$ moieties. Except for the evolved species, several weak peaks at $1256,1124,998,746$ and $603 \mathrm{~cm}^{-1}$ emerged due to $\mathrm{N}-\mathrm{NO}_{2}$, $\mathrm{C}-\mathrm{O}, \mathrm{OH}$ groups, $=\mathrm{CH}_{2}$ and $\mathrm{CO}_{2}$ during the period of this TGA-IR test. The above results indicate that for the slow-heating regime $\left(5^{\circ} \mathrm{C} / \mathrm{min}\right)$, the evolved species of AAC from the TGA-IR response were less than those of PACB.

For the heating rate of $40^{\circ} \mathrm{C} / \mathrm{min}$, the TGA-IR spectra of AAC and PACB are shown in the right side of Fig. 3. For AAC, the peaks at 2945 and $2307 \mathrm{~cm}^{-1}$ were due to the $=\mathrm{CH}_{2}$ groups with a symmetric stretching vibration and the $\mathrm{CO}_{2}$ peak from about $300 \mathrm{sec}\left(243^{\circ} \mathrm{C}\right)$ to the end. A higher concentration of $=\mathrm{CH}_{2}$ groups and $\mathrm{CO}_{2}$ peak was seen between 400 and $1100 \mathrm{sec}\left(310\right.$ to $\left.777^{\circ} \mathrm{C}\right)$. In addition, the absorbance from $400 \mathrm{sec}$ to the end (260 to $799^{\circ} \mathrm{C}$ ) showed slight peaks at 1744, 1278, 990 and $732 \mathrm{~cm}^{-1}$, which were attributed to $\mathrm{C}=\mathrm{O}$ stretching, $\mathrm{N}-\mathrm{NO}_{2}, \mathrm{OH}$ group and $=\mathrm{CH}_{2}$. For PACB, the absorbance peaks of $\mathrm{CO}_{2}, \mathrm{C}-\mathrm{O},-\mathrm{OH}$ and $=\mathrm{CH}_{2}$ groups at 2291, 1078, 1026 and $814 \mathrm{~cm}^{-1}$ showed from about $400 \mathrm{sec}\left(310^{\circ} \mathrm{C}\right)$ to the end. In addition, this time period and the decom- 

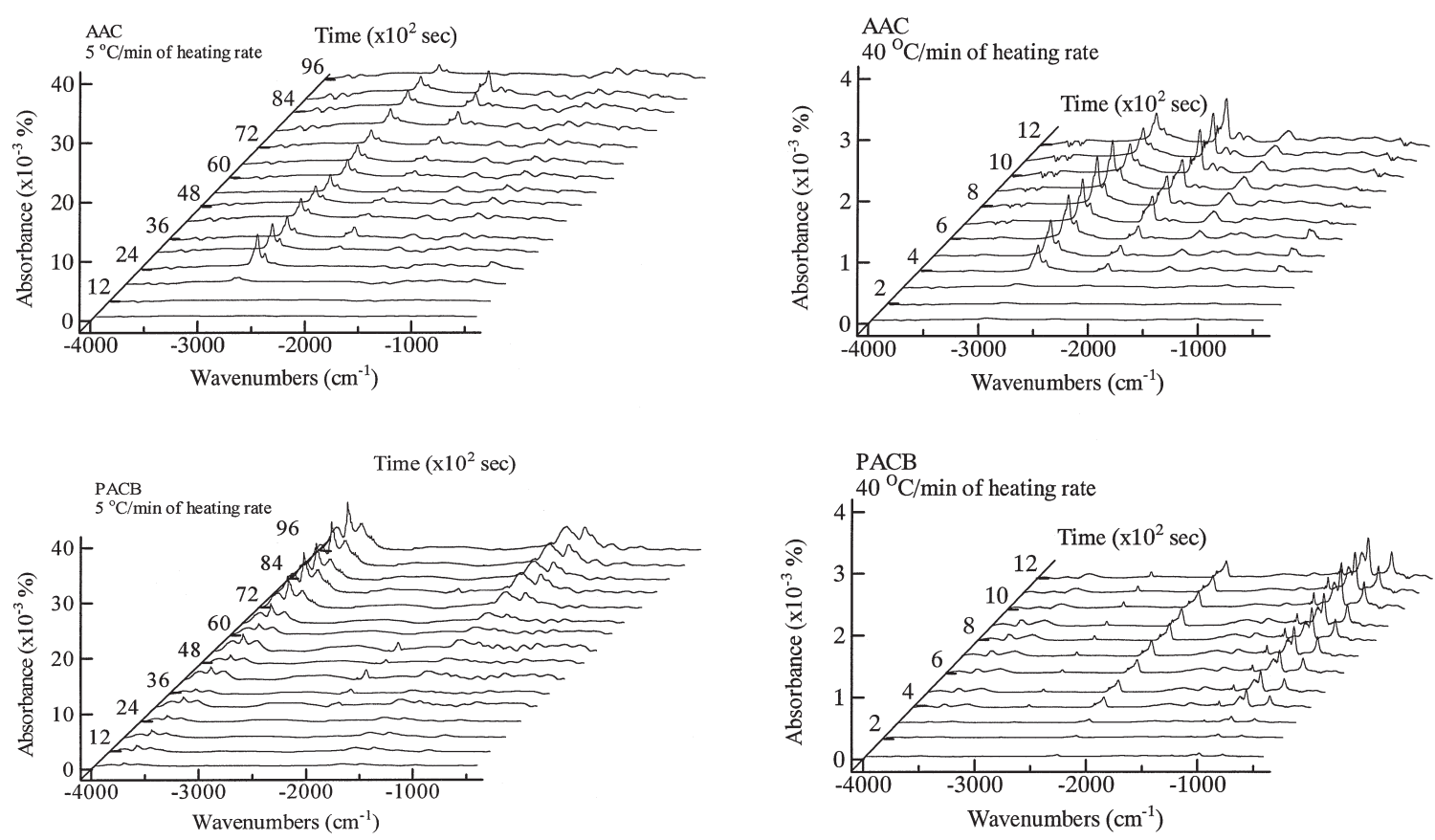

Fig. 3. TGA-IR spectra of 2 types of wood preservatives (AAC and PACB) in air with 5 or $40{ }^{\circ} \mathrm{C} / \mathrm{min}$. Note: Abbreviations of AAC and PACB are the same as Figure 1.

position temperature to the end also showed six slight peaks of absorbance at $3730,3521,2972,1514,1267$ and $617 \mathrm{~cm}^{-1}$, which were attributed to $\mathrm{N}-\mathrm{H},-\mathrm{OH},=\mathrm{CH}_{2}$, $\mathrm{C}-\mathrm{N}, \mathrm{N}-\mathrm{NO}_{2}$ groups and $\mathrm{CO}_{2}$ etc. These results indicate that at a heating rate of $40^{\circ} \mathrm{C} / \mathrm{min}$, AAC presented a much larger amount of evolved species than PACB.

When comparing the results of the IR response with the TGA-IR spectra of CCA and ACQ (Lin and Murase, 2007), we found that the concentration of the evolved species of both AAC and PACB was much higher than that of CCA, but less than that of ACQ. This is because these preservatives are composed of different chemical compounds that emit different volatiles during decomposition.

\section{Emission gases from AAC and PACB}

The results between the emission gas temperatures, concentration of $\mathrm{O}_{2}$ and $\mathrm{CO}_{2}$, and the combustion times for AAC and PACB are shown in Fig. 4. The increase in emission gas temperature corresponded to the increase in combustion time. The emission gas temperature for AAC increased linearly to about $129^{\circ} \mathrm{C}$ from the start of the combustion at $113.5 \mathrm{sec}$ and then decreased linearly to about $106^{\circ} \mathrm{C}$ at $151.0 \mathrm{sec}$. Then it finally decreased slightly to the end at $101{ }^{\circ} \mathrm{C}$. However, for PACB it was increased steadily to the end with the temperature at about $100{ }^{\circ} \mathrm{C}$. The emission gas temperature for AAC was found to be higher than that of PACB. This indicates that the ignition point and/or the heat decomposition temperatures of both preservatives are different because of the different chemical compounds (Lin et al., 2001; Lin et al., 2004; Lin et al., 2007).

The results also showed that an increase of $\mathrm{CO}_{2}$ and a decrease of $\mathrm{O}_{2}$ corresponded to the increase in com-
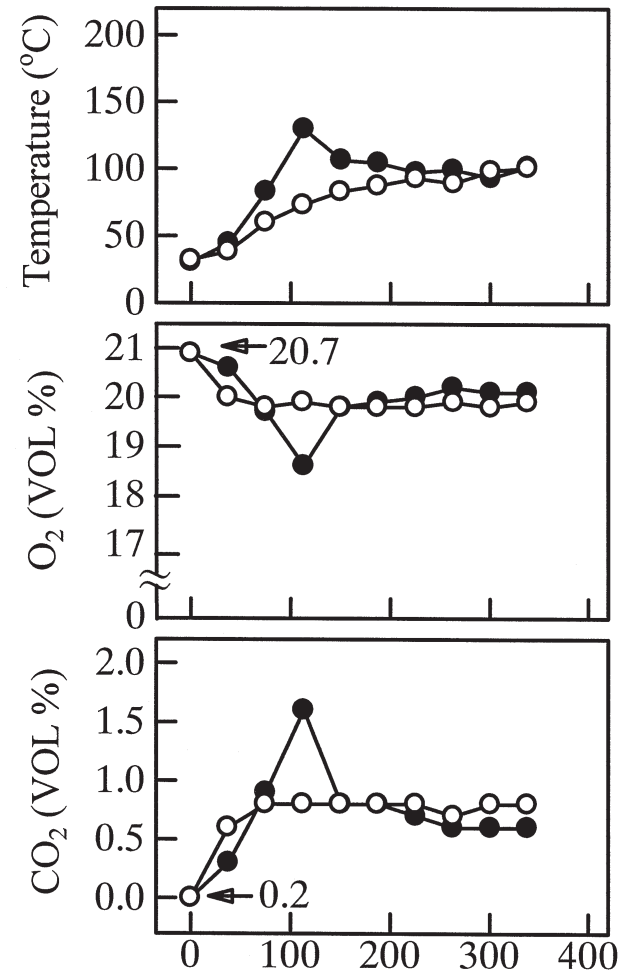

Combustion time (Sec)

Fig. 4. Relationships between combustion time and emission gas temperature, $\mathrm{O}_{2}, \mathrm{CO}_{2}$ concentration for AAC and PACB. Symbols: $\bullet$ : AAC; ——: PACB Note: Abbreviations of $\mathrm{AAC}$ and $\mathrm{PACB}$ are the same as Figure 1. 
bustion time for AAC and PACB, as shown in the middle and bottom of Fig. 4 respectively. The lowest $\% \mathrm{O}_{2}$ for AAC was about $18.6 \%$, and the peak for $\mathrm{CO}_{2}$ was about $1.6 \%$. The gas temperature reached about 105 to $110^{\circ} \mathrm{C}$ after $150.0 \mathrm{sec}$ and remained stable until the end of the combustion period. For PACB, the concentration of $\mathrm{O}_{2}$ decreased linearly from $20.7 \%$ to about $20.0 \%$. On the other hand, the concentration of $\mathrm{CO}_{2}$ increased from $0.2 \%$ to about $0.7 \%$. Both $\mathrm{O}_{2}$ and $\mathrm{CO}_{2}$ then reached a plateau until the end of the combustion time. The concentration of $\mathrm{O}_{2}$ was negatively related and $\mathrm{CO}_{2}$ was positively related to the emission gas temperature. The concentration of $\mathrm{O}_{2}$ and $\mathrm{CO}_{2}$ were closely related to each other. These results agree with those of Lin et al., 2001; Lin and Huang, 2004; Lin, 2005; Lin et al., 2005; Lin et al., 2007.

The results of the emission contents for the two types of preservatives are shown in Fig. 5. The peak for CO gas for AAC was found to be at $113.5 \mathrm{sec}$ with $94.0 \mathrm{ppm}$ after the beginning of combustion, and then decreased until the end of the combustion period. For PACB a maximum value of $\mathrm{CO}$ was reached at about $75.0 \mathrm{sec}$ with $120.0 \mathrm{ppm}$ from the start of combustion and then it decreased until the end. This indicated that the emission of CO gas is not only related to the ignition time (Ladomersky, 2000; Lin et al., 2001; Lin et al., 2004; Lin et al., 2007), but is also related to the incomplete combustion at different combustion times due to the different chemical compounds. This experiment found that no $\mathrm{SO}_{2}$ was being emitted by any of the preservatives

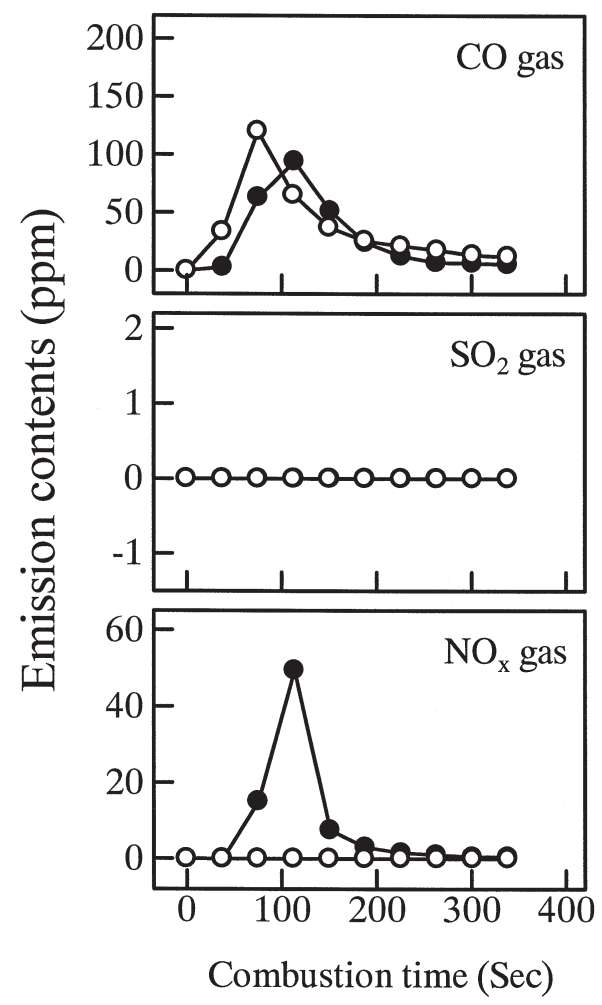

Fig. 5. Relationships between combustion time and emission contents for AAC and PACB. Note: Abbreviations of AAC, PACB and symbols are the same as Figure 1 and 4. during combustion. The results (see the bottom of Fig. 3) also showed that both AAC and PACB produced NOx gas. Although the amount of NOx gas produced was insignificant for PACB during the combustion, the peak of NOx gas for AAC was about $49.5 \mathrm{ppm}$ at about $113.5 \mathrm{sec}$ of the combustion period. NOx is considered to be the main source of pollution from burning AAC, and its amount was higher than that of ACQ and CCA (Lin et al., 2007). It is inferred that the ignition point and/or the heat decomposition of the preservatives may influence the combustion time and the quantity of emission gases, including NOx. The reason for NOx gases being created through the burning of these preservatives is due to the fact that they include $\mathrm{N}$ in their chemical compounds (Kercher and Nagal, 2001; Lin et al., 2006 and 2007).

\section{CONCLUSIONS}

This paper examined the pyrolysis temperature, the decomposition time of the evolved species, and the emission gas concentration of AAC and PACB. The results were then compared with those of previous works (Lin et al., 2007; Lin and Murase, 2007), and can be summarized as follows:

1. The decomposition temperature and the char (wt \%) of AAC and PACB for the heating rate of $5{ }^{\circ} \mathrm{C} / \mathrm{min}$ were lower than those at $40^{\circ} \mathrm{C} / \mathrm{min}$. Regardless of the different heating rates, both the decomposition temperature and the char (wt \%) of PACB were higher than these of AAC. Compared to the char results of CCA and ACQ, the char of PACB was higher than that of ACQ and lower than that of CCA.

2. The results of the IR response and the TGA-IR spectra from the TGA-IR tests showed that at a heating rate of $5^{\circ} \mathrm{C} / \mathrm{min}$, the main evolved species, the concentrations of $\mathrm{CO}_{2}$ and the evolved specie of $=\mathrm{CH}_{2}$ groups, of AAC were less than those of $\mathrm{PACB}$, but at $40^{\circ} \mathrm{C} / \mathrm{min}$ the results were reversed. Compared with the results of CCA and $\mathrm{ACQ}$, the absorbance of the $\mathrm{CO}_{2}$ peak of $\mathrm{AAC}$ and PACB was higher than that of CCA, but lower than that of ACQ.

3. The results of the combustion emissions showed that the highest emission quantity of CO was about $94.0 \mathrm{ppm}$ for AAC, and $120.0 \mathrm{ppm}$ for $\mathrm{PACB}$, and they were both higher than CCA and $\mathrm{ACQ}$. The emission quantity of $\mathrm{SO}_{2}$ for each sample type, including AAC, PACB, CCA and ACQ, was zero. The maximum NOx for AAC was about $49.5 \mathrm{ppm}$, and the value was higher than that for ACQ and CCA, but it was insignificant for the amount of PACB during the combustion.

It is evident from the above results that the use of TGA in combination with TGA-IR analysis for analyzing the thermal properties of preservatives has led to useful results, regarding the identification of thermal decomposition products (evolved species and char). The CEM analysis enabled us to determine the emission gas concentrations of $\mathrm{O}_{2}$ and $\mathrm{CO}_{2}$, the emission contents (CO, 
$\mathrm{SO}_{2}, \mathrm{NOx}$ ), and the temperature of the emission gases during the combustion of the preservatives.

\section{ACKNOWLEDGEMENTS}

The authors are grateful to the Te Feng Lumber Co. Ltd., Taiwan, for providing the experimental materials. We offer our sincere appreciation to the National Science Council through Grant No. NSC 94-2313-B-415-008 for financial support.

\section{REFERENCES}

Chang, Y. F., L. K. Wu, S. T. Li and H. F. Lan 2004 The Qualitative and Quantitative Analysis of Copper and Boron in P-ACB Wood Preservatives. Semina report, Dept. of Wood Science and Design, NPUST, Taiwan

China National Standard CNS 7614 A 31251994 Method of Test for Flammability of Thin Materials, China National Standard in Taiwan

China National Standard CNS 14495010182000 Wood Preservatives China National Standard in Taiwan

Cooper, P., T. Ung, F. Kazi and D. Qi 2003 Two Approaches of CCA Treated Wood: Extraction for Recycling and Wood Cement Composites. Presented at the AWPA Annual Meeting, Boston, MA

Cox, C. 1991 Chromated Copper Arsenate. J. of Pesticide Reform, 11(1): 2-6

Fan, Y. C. 2003 Protein/Ammoniacal Copper Borates as Benign Preservatives for China Fir, Japanes Fir and Makino Bamboo. Master Thesis, Dept. of Wood Science and Design, NPUST, Taiwan

Helsen, L. and E. Van den Bulck 2005 Review of Disposal Technologies for Chromated Copper Arsenate (CCA) Treated Wood Waste, with Detailed Analyses of Thermogravimetrical Conversion Processes. Environmental Pollution, 134: 301-314

Hirata, T., M. Inoue and Y. Fukui 1993 Pyrolysis and Combustion Toxicity of Wood Treated with CCA. Wood Sci Technol, 27: $35-47$

Ibach, R. E. 1999 Chapter 14 Wood preservatives. Wood Handbook - Wood as an Engineer Material. Forest Products Society, pp. 14-2 - 14-9

Jang, Y. M. 2000 Technique of Burning Process. WEN-JING Book Corp Taipei, pp. 62-81, 213-221, 421-430

Kercher, A. K. and D. C. Nagle 2001 TGA Modeling of the Thermal Decomposition of CCA Treated Lumber Waste. Wood
Science and Technology, 35: 325-341

Ladomersky, J. 2000 Emission analysis and minimization from the wood waste combustion. Drevarsky Vyskum, 45(4): 33-44

Lee, H. L., T. C. Shiah, F. L. Hsu and S. J. Lin 2005 Effects of New Waterborne Wood Preservatives on the Durability and Thermal Properties of Wood. Taiwan J. For Sci., 20(2): 139-156

Lin, H. C., J. C. Huang, Y Fujimoto and Y. Murase 2001 Analysis of gases emitted from particleboard combustion. Forest Products Industries, 20(2): 165-174

Lin, H. C. and J. C. Huang 2004 Analysis of Combustion Emissions from Wood Coatings after QUV Degradation, Journal of National Chiayi University, 1(1): 50-68

Lin, H. C., T. Ohuchi and Y. Murase 2004 Estimating Thermal Behavior and Analyzing Evolved Species of Adhesives through Thermogravimetric Analysis combined with Spectrometric Techniques. J. of Fac. Agr., Kyushu Univ., 49(2): 449-459

Lin, H. C. 2005 Potential Application of FTIR to Combustion Emissions Analysis of Degradation Coatedwood. Journal of Agriculture and Forest, National Chiayi University, $\mathbf{7 5}$ $15-40$

Lin, P. C., H. C. Lin, J. C. Huang and T. C. Shiah 2005 Evaluation on Strength Properties and Combustion Emissions from Particleboards with Various Manufactured Factors. Quart. Journal Forest Research of Taiwan, 27(1): 53-66

Lin, H. C., T. Ohuchi, Y. Murase, T.-C. Shiah, L. T. Gu, M. J. Lee 3 and Y. D. Wu 2006 Application of TGA and EDX Analysis to Evaluate the Process of Preservative-Treated Woods. J. of Fac. Agr., Kyushu Univ., 51(2): 337-344

Lin, H. C., T. Ohuchi and Y. Murase 2007 Analysis of Combustion Emissions and Char from CCA- and ACQ-Treated Woods. J. of Fac. Agr., Kyushu Univ., 52(1): 91-98

Lin, H. C. and Y. Murase 2007 Estimation of the Thermal Decomposition and Analysis of Evolved Species and Char of Wood Preservatives Using Thermogravimetric Analysis Combined with Spectrometric Techniques. J. of Fac. Agr., Kyushu Univ., 53(2): 371-380

Mazela, B. and P. R. Izabela 2003 Use of animal proteins to limit leaching of active copper ions preservatives form treated wood. Holzforschung 57: 593-596

Statheropoulos, M. and S. A. Kyriakou 2000 Quantitative thermogravimetric-mass spectrometric analysis for monitoring the effects of fire retardants on cellulose pyrolysis. Analytica Chimica Acta., 409: 203-214

Solo-Gabriele, H. M., T. G. Townsend and J. Schert 2003 Environmental Impacts of CCA Treated Wood: A Summary from Seven Years of Study Focusing on the US Florida Environment. Presented at the 34th Annual IRG Meeting, Brisbane, Australia, IRG/WP 03-50205 